\title{
MENGAMATI KEHIDUPAN OWA JAWA DALAM PENYUTRADARAAN FILM DOKUMENTER “HABITAT" DENGAN BENTUK PENUTURAN PERBANDINGAN
}

\author{
Kawakibi Muttaqien \\ Dyah Arum Retnowati \\ Gregorius Arya Diphayana \\ Jurusan Film \& Televisi, Fakultas Seni Media Rekam, Institut Seni Indonesia Yogyakarta \\ J1. Parangtritis km. 6.5 Yogyakarta Telp. (0274) 381047
}

\begin{abstract}
Documentary is one among many ways to tell a fact and information from surroundings. One of it are endemic animals called Javan Gibbon.

This thesis documentary tells about Javan Gibbon who lives in three different habitat which are wild life, rehabilitation center and zoo. Different environment influences the daily activiy of each Javan Gibbon. For Javan Gibbon, jungle is their natural habitat. Rehabilitaion center is a place for them to be rehabilitate before being release to wild life. While zoo is a place for preservation and education for people.

This thesis, Observing the Life of Javan Gibbon in Directing Documentary “Habitat" with Narrative Form of Comparison, contains the comparison of Javan Gibbon on three different habitats. The comparison is delivered with sequences of footages between each habitat through activities of Javan Gibbon. The activity consists of the process of getting food, socialize between each Gibbon, interacting with humans and during rainy seasons.
\end{abstract}

keywords: documentary, javan gibbons habitat, comparison, directing

\section{ABSTRAK}

Film dokumenter merupakan satu dari sekian banyak cara untuk menyampaikan sebuah fakta dan informasi dari apa yang terjadi di sekitar kita. Salah satunya adalah satwa endemik yaitu owa Jawa.

Karya tugas akhir film dokumenter ini menceritakan tentang owa Jawa yang hidup di tiga habitat yaitu alam liar, penangkaran rehabilitasi dan kebun binatang. Lingkungan yang berbeda mempengaruhi pola kehidupan sehari-hari dari masing- masing owa Jawa. Bagi owa Jawa, hutan merupakan habitat alaminya. Penangkaran merupakan tempat rehabilitasi sebelum dikembalikan ke alam liar. Sedangkan kebun binatang merupakan tempat pelestarian dan sarana edukasi bagi masyarakat.

Perbandingan owa Jawa ini dikemas dalam karya tugas akhir yang berjudul Mengamati Kehidupan Owa J awa dalam Penyutradaraan Film Dokumenter "H abitat" dengan Bentuk Penuturan Perbandingan. Perbandingan ini disampaikan dengan menyajikan runtutan gambar antara habitat satu dengan habitat lainnya melalui kegiatan owa Jawa. Kegiatan tersebut meliputi proses mendapatkan makanan, bersosialisasi dengan sesama owa Jawa, berinteraksi dengan manusia, dan menghadapi kondisi cuaca seperti hujan.

kata kunci: film dokumenter, habitat owa jawa, perbandingan, penyutradaraan

\section{Pendahuluan}

Film dokumenter "Habitat" adalah karya Tugas Akhir Skripsi Penciptaan Seni yang dibuat untuk memenuhi syarat kelulusan strata satu Jurusan Televisi, Fakultas Seni Media
Rekam, Institut Seni Indonesia Yogyakarta.

Dokumenter ini mengangkat perbandingan kehidupan satwa endemik Indonesia di beberapa habitat yang berbeda. Satwa yang dijadikan fokus utama adalah owa Jawa. 


\section{Kawakibi Muttaqien, Dyah Arum Retnowati, Gregorius Arya Diphayana}

Mengamati Kehidupan Owa Jawa Dalam Penyutradaraan Film Dokumenter "HABITAT"

Kehidupan owa Jawa dibawakan melalui tiga jenis habitat yang berbeda-beda yaitu alam liar, penangkaran rehabilitasi dan kebun binatang.

Owa Jawa merupakan primata endemik dari Indonesia. Penyebaranya terletak di pulau Jawa, spesifiknya berada di Jawa Tengah dan Jawa Barat. Owa Jawa memiliki bulu di sepanjang tubuhnya yang berwarna abu-abu. Bagian wajahnya berwarna hitam. Primata ini memiliki tangan yang panjang melebihi besar tubuhnya yang digunakan untuk berayun dari satu pohon ke pohon lainnya dikarenakan owa Jawa merupakan primata arboreal yang menghabiskan kegiatan sehariannya di atas pohon. Kera ini hidup dalam satu keluarga kecil yang terdiri atas satu induk jantan dan satu induk betina beserta individu anak dengan menetap di satu tempat sebagai rumah, biasanya di atas pohon. Owa Jawa terkenal dengan kesetiaannya dalam berpasangan. Berbeda dengan kera lainnya dimana seekor jantan memiliki pasangan lebih dari satu betina. Owa Jawa merupakan primata monogami, hanya memiliki satu pasangan selama hidupnya. Dia tidak akan berpaling dari pasangannya meskipun ditinggal mati justru ia akan dilanda stres dan ikut mati. Hal ini yang kemudian menjadikan owa Jawa salah satu binatang yang terancam punah akibat perburuan anak owa untuk dijadikan hewan peliharaan dengan cara menembak mati induk betinanya dan juga membunuh induk jantannya.
Seperti manusia, binatang juga memiliki tempat tinggal yang berbeda-beda. Tempat tinggal tersebut mempengaruhi perilaku keseharian mereka tergantung bagaimana situasi sekelilingnya. Ketiga tempat tinggal atau habitat yang dijadikan objek utama dari film dokumenter "Habitat" adalah alam liar, penangkaran rehabilitasi dan kebun binatang. Kebun binatang merupakan penangkaran buatan manusia yang diletakkan di dalam kota agar masyarakat bisa dengan mudah menjangkau dan melihat berbagai spesies binatang. Alam liar dapat didefinisikan sebagai suatu tempat terbentang luas yang merupakan habitat untuk binatang. Salah satu dari banyaknya habitat merupakan hutan tropis yang merupakan habitat bagi owa Jawa. Penangkaran rehabilitasi merupakan tempat untuk melatih owa Jawa eks peliharan tentang alam liar agar nantinya ketika dilepaskan memiliki pengetahuan bertahan hidup. Proses hingga dilepaskannya berlangsung lama tergantung bagaimana perkembangan dari individu owa Jawa itu sendiri.

Gagasan ini muncul pertama karena ketertarikan dalam dunia fauna. Banyaknya kabar berita mengenai perburuan, hilangnya habitat dan kepunahan hewan-hewan langka menjadi pemicu untuk mengangkat tema mengenai binatang. Berkurangnya jumlah satwa dari tahun ke tahun menunjukkan 
ketidak pedulian manusia terhadap binatang.

Keingin menyajikan kehidupan owa Jawa di tiga tempat tersebut lewat film dokumenter menggunakan bentuk bertutur perbandingan. Diberikan melalui serangkaian gambar yang diambil secara nyata tanpa adanya intervensi dari pembuat. Hal itu dilakukan dengan maksud agar penonton dapat melihat dan merasakan kegiatan owa Jawa secara nyata sehingga bisa menimbulkan rasa kepedulian mereka.

Film dokumenter "Habitat" ini hanya akan bercerita melalui visual tanpa adanya bantuan penjelasan informasi melalui narasi atau teks. Gambar-gambar yang disajikan secara beruntun akan memberikan impresi kepada penonton sehingga membuatnya merasa ikut masuk ke dalam film tersebut dan memahami situasi yang ada. The impression that the filmmaker is not intruding on the behavior of others also raises the question of unacknowledged or indirect intrusion. (Nichols 2001, 111)

Film dokumenter "Habitat" menggunakan bentuk bertutur perbandingan untuk menjalankan cerita mengingat adanya tiga subjek yang berbeda sehingga bentuk penuturan ini dirasa tepat. Dokumenter ini dapat dikemas ke dalam bentuk dan tema yang bervariasi, selain dapat pula digabungkan dengan bentuk penuturan lainnya, untuk mengetengahkan sebuah perbandingan. Dalam bentuk perbandingan umumnya diketengahkan perbedaan suatu situasi atau kondisi, dari satu objek/subjek dengan yang lainnya. (Ayawaila 2017, 43)

\section{Pembahasan}

Film dokumenter "Owa Jawa" akan memaparkan perbedaan tempat tinggal dari owa Jawa di hutan, tempat rehabilitasi dan kebun binatang. Disampaikan dengan runtutan gambar-gambar yang berkesinambungan namun dengan perbedaan kegiatan harian mereka. Gambargambar yang disajikan akan menggunakan metode long take dengan maksud agar dapat memfokuskan penonton terhadap situasi yang terekam dan juga kegiatan-kegiatan yang dilakukan oleh subjek tanpa adanya intervensi apapun dari pembuat film sehingga menjadi sebuah adegan yang natural. Dalam pembuatan dokumenter ini, momen menjadi sebuah hal yang sangat dinantikan. Keunikan dari binatang adalah bagaimana tingkah laku lugu mereka yang tidak bisa dilihat sehari-hari. Bagaimana kebiasaan yang tidak banyak orang tahu sehingga akan menjadi nilai tambah untuk dokumenter ini.

Dokumenter ini tidak akan ada gambar wawancara dengan narasumber yang menyampaikan informasi. Sepanjang film hanya akan menyajikan rentetan gambar beradegan panjang. Informasi dari hasil riset dan wawancara hanya akan digunakan sebagai panduan dalam mengamati keseharian dan pencarian titik tempat subjek berpindah. Maka dari itu, 
dalam dokumenter ini segala informasi mengenai owa akan disajikan melalui gambar yang dibangun melalui perbedaan kedua habitat.

\section{Disain Program}

1. Bentuk Film: Dokumenter pendek

2. Judul : Owa Jawa

3. Tema : Perbandingan hidup owa Jawa di tiga tempat berbeda.

4. Durasi : 15 menit.

5. Segmentasi :

a. Usia : Semua umur

b. Sex : Unisex

\section{Film Statement}

Film dokumenter "Owa Jawa" akan memperlihatkan perbedaan kehidupan owa Jawa di hutan, tempat rehabilitasi dan kebun binatang.

\section{Sinopsis}

Meski hutan, penangkaran dan kebun binatang memiliki fungsi yang sama sebagai tempat tinggal namun yang membedakan mereka adalah situasi sekelilingnya. Seperti halnya manusia, lingkungan menjadi salah satu faktor utama yang menentukan tingkah laku seseorang. Pada primata owa Jawa, ketiga habitat yang berbeda tentu juga akan mempengaruhi psikologis mereka. Owa yang menghabiskan semasa hidupnya di hutan tentu akan bisa bertahan hidup sendiri, menghadapi serangan dari predator, mencari makan dan lari jika melihat manusia. Lain lagi dengan owa yang hidup di kebun binatang, di sebuah kandang yang ruang geraknya terbatas, tidak perlu khawatir kekurangan makanan karena disiapkan oleh penjaganya, selain itu karena kesehariannya selalu berinteraksi dengan manusia, mereka tidak akan ketakutan namun justru mengharapkan kehadiran manusia untuk mengurangi rasa bosan mereka. Sementara di penangkaran, fungsi utamanya adalah merehabilitasi owa Jawa sitaan warga eks peliharaan agar bisa kembali ke alam liar nantinya. Proses rehabilitasi tersebut berjalan dalam jangka waktu yang panjang. Sifat owa Jawa yang baru masuk kurang lebih akan sama seperti owa Jawa di kebun binatang dan diharapkan ketika dilepas kembali ke alam liar akan memiliki sifat yang cenderung sama dengan owa Jawa liar. Ketiga habitat tersebut menimbulkan pertanyaan mengenai perbandingan yang muncul bagi ketiga owa Jawa.

\section{Pra Produksi}

Tahap pra produksi film dokumenter "Habitat" meliputi proses pencarian ide. Kemudian melakukan riset terhadap subjek yang diangkat dengan cara terjun langsung ke lapangan atau melakukan wawancara dengan ahlinya. Pada tahap ini segala bentuk informasi harus didapatkan sebaik mungkin sebagai bahan acuan untuk saat pengambilan gambar dan juga proses membuat alur cerita dalam film. Berikut penjabaran tahap pra produksi film dokumenter "Habitat": 


\section{Pencarian Ide}

Owa Jawa dipilih sebagai subjek karena keunikkannya. Primata ini merupakan primata yang setia pada pasangan dan hidup dalam satu kelompok yang merupakan keluarganya. Jika induk jantan kehilangan induk betina, ia akan stres dan berujung pada kematian. Di Gunung Gede Pangrango terdapat hutan lindung yang merupakan habitat owa Jawa liar. Di sana mereka hidup dengan bebas di teritorial yang mereka miliki. Satu teritorial owa Jawa seluas 15 hektar yang dihuni oleh satu keluarga terdiri atas satu induk jantan, satu induk betina dan beberapa anakan. Selain hutan lindung, di Gunung Gede Pangrango juga terdapat sebuah penangkaran owa Jawa yang memiliki misi untuk merehabilitasi owa Jawa sitaan masyarakat agar bisa dilepas liarkan kembali ke alam liar. Maka dari itu semasa proses rehabilitasi, semua owa Jawa diusahakan untuk tidak bertemu dengan manusia ataupun berinteraksi agar nantinya ketika dilepas ke alam liar tidak akan mendekati manusia. Berbeda dengan kebun binatang, di salah satu kebun binatang di Jakarta terdapat sebuah kandang yang berisi satu ekor owa Jawa tanpa pasangan sehingga kesehariannya hanya berdiam diri tanpa ada interaksi apapun terhadap pasangan (sesama owa Jawa). Namun inilah yang menjadikan owa Jawa tersebut unik karena bukannya berinteraksi dengan pasangan sesama owa Jawa, primata ini melakukan interaksi dengan manusia yaitu pengunjung.

\section{Riset}

Tahap riset dilakukan dengan cara terjun langsung ke lapangan yaitu alam liar, penangkaran dan kebun binatang. Riset dilakukan dengan cara mengobservasi kegiatan owa Jawa di masing-masing lokasi dalam satu harinya. Pengamatan owa Jawa di alam liar didampingi dengan penjaga hutan yang sudah memahami keadaan di hutan dan juga kebiasaan owa Jawa yang berada di daerah tersebut. Sehingga dalam perjalanan menelusuri hutan selalu didampingi dan diberi arahan ke tempattempat yang biasa muncul primata ini.

\section{Pembuatan Treatment}

Treatment dibuat setelah selesai melakukan riset lapangan terhadap subjek yang diangkat. Film dokumenter "Habitat" diawali dengan memberikan gambaran tiga tempat yang akan dijadikan bahasan utama yaitu hutan, penangkaran dan kebun binatang. Dilanjutkan dengan pengenalan satwa masing-masing yang ada di tempat tersebut, kemudian beralih ke bagaimana masing-masing owa Jawa di ketiga tersebut memperoleh makanan untuk mereka konsumsi. Pembahasan lainnya adalah bagaimana masing- masing bersosial menurut habitat dan juga bagaimana pergerakan mereka.

\section{Produksi}

Tahap selanjutnya setelah pra produksi adalah proses pengambilan 


\section{Kawakibi Muttaqien, Dyah Arum Retnowati, Gregorius Arya Diphayana}

Mengamati Kehidupan Owa Jawa Dalam Penyutradaraan Film Dokumenter "HABITAT"

gambar. Tim berangkat menuju lokasi pengambilan pertama sesuai jadwal yaitu di hutan, kemudian dilanjutkan dengan pengambilan gambar di penangkaran dan terakhir di kebun binatang.

\section{Pengambilan Gambar}

Pengambilan pertama di penangkaran cukup memakan waktu namun tidak banyak kendala. Persiapan awal sebelum memulai ambil gambar adalah pembuatan bipak yaitu tempat untuk bersembunyi dari penglihatan owa Jawa di dalam kandang.

Bipak dibuat menggunakan bahan-bahan kayu yang dicari di sekitar lokasi. Disusun dan ditutup dengan atap berupa terpal coklat dan juga daun-daun untuk kamuflase. Bagian depan ditutup oleh dedaunan untuk menutupi pengambil gambar dari arah pandang owa Jawa. Bipak dibuat di satu kandang yang dijadikan subjek utama dan diletakkan di tiga sudut agar mendapatkan variasi arah angle kamera. Kamera diletakkan di dalam bipak dan lensa dikeluarkan di sela- sela daun yang menutupi sehingga tidak terlihat. Selama pengambilan gambar juga diusahakan untuk tidak membuat suara agar owa Jawa tidak mendeteksi adanya sesuatu.

Proses pengambilan gambar di lokasi alam liar tidak menggunakan bipak namun tetap bersembunyi dibalik semak-semak atau pepohonan. Guide mengarahkan ke lokasi yang biasa dilewati owa Jawa. Terkadang dapat ditemukan binatang lain seperti lutung Jawa, surili atau monyet ekor panjang. Meskipun sudah diperkirakan bahwa owa Jawa biasa muncul di satu tempat namun tidak dapat dipastikan mereka akan muncul di sana setiap harinya. Kemunculan owa Jawa di hutan tidak dapat diprediksi sehingga harus bersabar selama menunggunya dan harus bergerak dengan cepat untuk mengambil gambarnya. Mengingat primata ini tidak pernah turun ke tanah, dataran tinggi menjadi tempat utama untuk menunggu sehingga dapat menangkap gambar dengan arah pandang yang sejajar. Owa Jawa yang berada di alam selalu memasang posisi waspada. Setiap kali melihat adanya pergerakan, primata ini langsung memasang pandangan ke arah gerakan tersebut dan memasang posisi untuk lari. Bersembunyi ketika mengambil gambar sangat diwajibkan. Jika owa Jawa merasa terancam seperti melihat rombongan manusia, mereka akan berteriak memberikan sinyal kepada keluarganya lalu berlari sekencang mungkin dari pohon ke pohon untuk menyelamatkan diri. Jadi, menunggu dan tidak membuat suara atau gerakan menjadi poin penting dalam mengambil gambar di hutan. Ketika owa Jawa yang ditunggu muncul, dipastikan semua kamera harus dalam keadaan siap sehingga tidak kehilangan momen penting.

Di kebun binatang kurang lebih sama seperti di penangkaran namun tidak membuat bipak dikarenakan owa Jawa di kebun binatang sudah terbiasa bertemu dengan manusia. Proses pengambilan 
gambar dilakukan dengan hati-hati dikarenakan tidak ingin mengganggu aktivitas pengunjung lainnya yang berinteraksi dengan owa Jawa. Subjek di kebun binatang merupakan owa Jawa yang paling unik dibandingkan yang lainnya. Hal ini dikarenakan interaksinya dengan manusia yang sangat mudah untuk diraih. Setiap kali pengunjung menghampiri kandang tersebut, subjek mengulurkan tangannya dan menggenggam erat tangan pengunjung. Selain itu, subjek juga mau menerima makanan pemberian pengunjung seperti biskuit ataupun roti. Dari tiga kandang owa Jawa di kebun binatang hanya owa Jawa inilah yang memiliki keunikan tersebut sehingga dijadikan subjek utama.

Selama proses pengambilan gambar ditemukan berbagai macam kesulitan dan kejadian yang diluar rencana. Bahkan terdapat beberapa perencanaan yang tidak memungkinkan untuk dilakukan namun tetap dimaksimalkan agar eksekusi tidak berubah jauh dari perencanaan.

\section{Pasca Produksi}

Setelah proses produksi selesai dan dirasa cukup dengan semua footage nya maka dilakukan penyusunan gambar sehingga menjadi satu kesatuan cerita yang utuh. Film dokumenter "Habitat" menggunakan bentuk bertutur perbandingan dalam menyampaikan ceritanya. Setiap footage dari masing-masing habitat disandingkan satu sama lain agar terlihat perbedaannya. Perbedaan tersebut diwakilkan oleh kegiatan yang dilakukan oleh owa Jawa. Dalam prosesnya, penggunaan crosscutting akan sering digunakan untuk menyandingkan beberapa gambar di tiap tempat yang berbeda. Setiap perbandingan disusun tergantung fokus kegiatan yang dilakukan oleh tiap owa Jawa seperti sedang makan, bersosial, kondisi alam yang hujan dan sebagainya. Banyaknya kegiatan yang dilakukan dan diambil dalam kurun waktu yang berbedabeda menjadikan footage yang dimilki berbeda warna, cahaya atau atmosfirnya.

\section{Rough Cut}

Di tahap ini gambar-gambar yang sudah disusun kemudian dirangkai menjadi cerita yang utuh. Pada tahap ini biasanya diperhatikan unsur continuity dalam film. Namun dalam film dokumenter "Habitat" ini tidak begitu mengikuti continuity tiap gambarnya dikarenakan pergerakan yang dilakukan owa Jawa sangat cepat dan hanya diambil menggunakan satu kamera. Cutting tiap gambar disesuaikan menurut habitat dan kegiatannya

\section{Sound Mixing \& Music Scoring}

Sound mixing merupakan proses penyelarasan suara dengan gambar. Suara yang dihasilkan dari gambar satu ke gambar lain diratakan, sehingga tidak ada suara yang begitu tinggi atau rendah. Proses ini sangat penting karena akan mempengaruhi emosi dalam film. 
Music scoring adalah proses pembuatan musik latar. Dalam film dokumenter "Habitat", musik yang dibuat akan diletakkan di bagian pembuka dan penutup saja. Sepanjang cerita dalam film tidak akan diberikan musik apapun dikarenakan ingin menyajikan suara asli dari masing-masing tempat, sehingga terdengar natural tanpa ada intervensi suara lain.

\section{Color Grading}

Proses ini dilaksanakan bersamaan dengan sound mixing. Sesuai namanya, color grading merupakan proses mewarnai footage dari film yang sudah selesai disusun. Dalam film dokumenter "Habitat" tidak begitu menggunakan warna yang menonjol. Pada proses ini hanya akan menyamakan warna, gelap dan terang dari masing-masing gambar dikarenakan selama proses produksi selalu berhadapan dengan kondisi cuaca yang mengakibatkan naik dan turunnya cahaya.

\section{Pembahasan Karya}

Struktur penceritaan film ini disampaikan secara tematis. Pada awal film akan dibuka dengan mengenalkan ketiga habitat tersebut dan juga owa Jawa yang menjadi subjek. Kemudian dilanjutkan dengan menampilkan keseharian seluruh owa Jawa yang sama yaitu makan, sosial dan bergerak. Masing- masing disandingkan satu sama lain agar terlihat perbedaan ketiganya secara jelas. Cerita disampaikan menggunakan bentuk bertutur perbandingan. Bentuk ini dipilih karena dapat dengan mudah menyajikan perbedaan ketiga tempat dan dibandingkan satu sama lain.

\section{Naratif}

Dalam penceritaannya, film dokumenter "Habitat" terbagi atas 6 segmen yang disajikan dengan runtutaan gambar beradegan panjang tanpa adanya narasi dan teks. Segmen pertama memperkenalkan masing-masing habitat beserta isinya. Segmen kedua memperkenalkan satwa owa Jawa di masing-masing habitat yang menjadi subjek bahasan. Segmen ketiga akan memperlihatkan bagaimana cara makan masing- masing owa Jawa. Segmen keempat memperlihatkan aktivitas harian owa Jawa seperti bersosial dengan manusia atau sesamanya. Segmen kelima menunjukkan situasi masing- masing alam dan owa Jawa di dalamnya ketika dalam keadaan hujan. Segmen keenam atau terakhir memberikan konklusi siklus harian mereka pada akhirnya. Berikut adalah detail setiap segmen:

\section{Segmen 1: Pengenalan habitat}

Film dokumenter "Habitat" diawali dengan montage pemandangan alam di hutan beserta satwa yang berada di dalamnya. Berbagai macam satwa menunjukkan bahwa hutan ini masih layak menjadi tempat tinggal untuk mereka dan merupakan habitat yang baik.

Dilanjut dengan gambaran kebun binatang secara umum seperti pengunjung yang belalu-lalang dan juga hewan yang 
berada di dalam kandang. Banyaknya pengunjung yang datang memberikan kesan hidup untuk kebun binatang ini sebagai tujuan tempat wisata.

Montage ini digambarkan secara beruntun untuk memperkenalkan perbandingan awal dari setiap lokasi yang akan diangkat. Pada segmen ini tidak menampilkan habitat di penangkaran dikarenakan di habitat tersebut hanya ada owa Jawa. Segmen pertama diakhiri dengan kemunculan judul film dan ditutup dengan layar hitam.

\section{Segmen 2: Pengenalan Owa Jawa}

Memasuki isi dari segmen pertama, diawali dengan establish hutan di pagi hari yang penuh kabut. Diiringi dengan suara nyanyian owa Jawa yang menuntun gambar kepada kemunculan owa Jawa di tengah kabut. Owa Jawa yang berada di hutan terlihat bergerak secara leluasa dan bebas melompat dari satu pohon ke pohon lainnya.

Pengenalan berikutnya adalah penangkaran Javan Gibbon Center. Dimulai dengan establish sekitaran penangkaran yang masih berada di dalam hutan. Memiliki gedung untuk tempat tinggal penjaga dan juga papan nama dari tempat tersebut.

Memasuki ke dalam penangkaran menampilkan subjek owa Jawa yang menjadi fokus utama di penangkaran. Satu keluarga owa Jawa di dalam kandang terdiri atas individu jantan, individu betina dan juvenile (anak). Masing-masing owa Jawa diperkenalkan melalui satu shot secara individu.

Habitat ketiga adalah kebun binatang. Gambar diawali dengan papan penunjuk jalan yang memberitahukan lokasi kandang. Terlihat di papan penunjuk tersebut terdapat tulisan primata yang kemudian menuntun gambar selanjutnya ke establish kandang primata. Di dalamnya terdapat owa Jawa di dalam kandang sendirian. Shot luas memberikan informasi luas kandang yang dilanjutkan dengan shot close up wajah owa Jawa dan juga papan nama binatang.

\section{Segmen 3: Makanan}

Segmen ketiga akan memperlihatkan bagaimana masing- masing owa Jawa memperoleh asupan. Ketiga habitat menyediakan pakan yang berbeda-beda. Bahkan pakan yang dikonsumsi pun berbeda tergantung owa Jawa itu sendiri. Segmen ini diawali dengan penangkaran, gambar awal adalah buah-buahan serta sayur pasar seperti pepaya, melon, wortel dan timun. Kemudian dilanjut dengan gambar buah hutan seperti buah afrika dan buah teureup. Lalu dedaunan seperti kangkung. Semua jenis makanan ini disiapkan berdasarkan waktu yang berbedabeda. Setelah pakan selesai disiapkan, penjaga kandang membawa pakan tersebut mengenakan atribut lengkap dengan masker untuk menjaga kesehatan owa Jawa. Pakan tersebut diletakkan di keranjang makanan 
yang sudah disiapkan di bagian luar kandang.

\section{Segmen 4: Sosial dan Interaksi dengan manusia}

Owa Jawa di hutan memiliki tingkat kewaspadaan yang tinggi. Jika merasa ada bahaya, mereka akan membuat suara-suara yang menandakan muncul bahaya. Suara itu dapat terdengar hingga ke ujung hutan. Owa Jawa yang mendengarnya dan berada di dekat suara tersebut akan berlarian dengan cepat untuk menyelamatkan diri. Sehingga jarang sekali owa Jawa muncul ke kerumunan orangorang yang membuat pengunjung tidak bisa menyaksikan owa Jawa liar secara langsung.

Kontras, kebun binatang memiliki fungsi untuk mempertunjukkan binatang di dalam kandang dengan maksud memberi pengetahuan kepada pengunjung. Mudah sekali bagi orangorang untuk melihat sosok owa Jawa dari jarak yang sangat dekat. Tidak hanya melihat, owa Jawa di kebun binatang ini justru memberikan tangannya mengharapkan sentuhan dari para pengunjung. Interaksi seperti ini hanya mungkin dilakukan oleh binatang yang berada di kebun binatang dikarenakan mereka sudah terbiasa melihat manusia dari jarak dekat setiap harinya.

Di penangkaran, tidak diperbolehkan ada pengunjung yang masuk ke area penangkaran. Satu- satunya manusia yang diperbolehkan keluar masuk adalah para penjaga kandang. Itu pun hanya sebatas untuk memberikan makanan di jam yang sudah ditentukan. Harapannya adalah agar owa Jawa di dalam penangkaran memiliki sifat seperti mereka yang ada di hutan. Kegiatan sosial untuk owa Jawa di penangkaran hanya berada di sekitar kandang mereka yaitu bersama keluarganya.

\section{Segmen 5: Hujan}

Segmen kelima akan menunjukkan situasi habitat ketika dilanda fenomena alam yaitu hujan. Dimulai dengan menunjukkan awan mendung dan hujan yang turun dengan sangat deras di hutan disertai petir. Keadaan di alam liar sangat kelam disaat hujan turun. Owa Jawa tidak terlihat dikarenakan hujan yang sangat deras. Biasanya mereka bersembunyi di atas pohon di bagian yang ditutupi banyak dedaunan.

Dilanjutkan dengan kondisi di penangkaran, dapat dilihat bagaimana subjek di penangkaran melindungi diri dari air hujan di tempat yang telah disediakan. Namun meski hujan, mereka tetap bercengkerama dan bercanda seakan hujan tidak menjadi masalah.

Sementara di kebun binatang terlihat owa Jawa yang sendirian menghadapi hujan. Kandang yang ditempati tidak memiliki atap yang menutup secara keseluruhan, hanya sebagian kecil. Subjek terlihat menunggu di lantai. Hal ini sangat bertolak belakang dengan sifat utama owa Jawa yang arboreal.

\section{Segmen 6: Siklus Kehidupan di Tiga Habitat}

Memasuki segmen keenam dan terakhir yang akan membahas bagaimana pada akhirnya siklus kehidupan ketiga 
habitat yang dihuni oleh masing-masing owa Jawa. Sesuai fungsinya masing-masing dan juga lingkungannya, ketiga habitat memberikan pola hidup yang juga berbeda. Setelah semua bahasan kegiatan dari makan, sosial dan berhadapan dengan fenomena alam. Pada akhirnya semuanya merupakan salah satu pola keseharian yang monoton. Konklusi akhir siklus kehidupan ketiga habitat pun berbedabeda. Penangkaran akan melepaskan owa Jawa yang sudah lama dirawat dan mengembalikan mereka ke habitat aslinya untuk bergabung dengan owa Jawa liar lainnya. Kandang yang tadinya dihuni oleh satu keluarga owa Jawa pun menjadi kosong dan akan menunggu penghuni baru lainnya. Di alam liar, setiap owa Jawa tetap akan menjalani kehidupan yang sama hanya saja ruang jelajah dan gerak mereka sangat besar sehingga kelincahan dan kebebasan dapat dirasakan. Sementara di kebun binatang, owa Jawa akan terus menerus mengalami kegiatan yang serupa dengan menunggu diam di dalam kandang. Satusatunya cara untuk melepas kesendirian dan rasa bosan adalah dengan kehadiran pengunjung yang melihatnya.

\section{Sinematik}

Elemen-elemen visual dibutuhkan untuk membungkus sebuah karya audio visual demi tercapainya hasil yang maksimal. Elemenelemen tersebut adalah elemen gambar, cahaya dan suara. Setiap elemen dikonsepkan terlebih dahulu sebelum memasuki proses pengambilan gambar. Beberapa elemen visual yang digunakan dalam film dokumenter "Habitat" adalah sebagai berikut:

\section{Elemen Gambar}

Film dokumenter "Habitat" mengedepankan penggunaan kamera secara still tanpa ada pergerakan dan dengan pengambilan long take. Teknik ini digunakan karena efek yang diberikan adalah membuat penonton melebur ke dalam adegan yang ditampilkan tanpa adanya intervensi apapun. Fokus pandangan akan ke subjek yang bergerak dalam frame.

Konsep yang sudah dibuat tidak selamanya berjalan sesuai rencana. Terdapat beberapa momen dimana penggunaan handheld menjadi sangat diperlukan. Pertimbangannya adalah untuk mengejar momen atau dataran yang tidak rata sehingga sulit untuk mendirikan tripod. Walaupun begitu, tetap diusahakan agar pergerakkan kamera tidak terlalu besar dan membuat mata tidak nyaman ketika melihatnya.

Pencahayaan pada dokumenter "Habitat" bergantung penuh kepada alam. Perubahan cuaca yang ekstrim setiap harinya menjadi tantangan dalam pengambilan gambar.

\section{Elemen Suara}

Elemen suara menjadi hal penting dalam proses pengambilan gambar. Tetapi, poin penting ini cukup terlupakan. Hal ini dikarenakan kurangnya jumlah kru. Semasa 
pengambilan gambar di hutan dan kebun binatang dilakukan secara sendiri sehingga fokus utama hanya pada gambar. Namun, penggunaan Rode VideoMic Go tetap digunakan dipasangkan pada kamera. Mic tersebut digunakan untuk mengambil suara atmosfir di lokasi. Secara hasil, film dokumenter ini tidak akan menampilkan narasi atau informasi apapun secara verbal. Seluruh elemen suara pada film ini hanya berasal dari atmosfir sekitar yang diambil saat kamera merekam kejadian. Selain itu, musik akan dijadikan opsi apabila dirasa perlu untuk meningkatkan mood adegan yang disajikan. Walau begitu, tidak akan memasukkan musik di setiap segmen karena dirasa akan mengganggu fokus utama penceritaan. Musik akan diletakkan di pembukaan dan penutup film menuju end credits.

\section{Kesimpulan}

Berdasarkan fungsinya, ketiga habitat tersebut berbeda-beda. Hutan memiliki fungsi salah satunya adalah sebagai habitat asli bagi beberapa satwa seperti monyet, burung, serangga atau binatang buas. Penangkaran memiliki fungsi untuk merehabilitasi owa Jawa sitaan dari warga untuk menghilangkan kebiasaan yang tidak seharusnya agar nantinya bisa kembali dilepaskan ke alam liar. Sementara kebun binatang memiliki fungsi untuk melindungi dan memperkenalkan satwa kepada manusia guna ilmu pengetahuan.
Secara fungsi memang berbeda, namun perbedaan yang dialami oleh ketiga habitat tersebut ternyata sangat bertolak belakang bagi penghuninya.

Meski terlihat kontras, namun masing-masing tempat memiliki kelebihan dan kekurangannya. Di hutan, walau terlihat bebas dan sangat aktif bergerak, namun terdapat kemungkinan owa Jawa liar akan diburu oleh pemburu liar atau kehilangan lahan tempat tinggal karena penebangan pohon. Di kebun binatang, meski terlihat tragis karena sendiri di satu kandang, namun owa Jawa tersebut tidak perlu khawatir akan diburu atau kekurangan makanan. Diantara keduanya terdapat penangkaran yang berfungsi sebagai solusi untuk owa Jawa yang tidak berperilaku layaknya owa Jawa seharusnya untuk direhabilitasi agar bisa dikembalikan ke alamnya.

\section{Daftar Pustaka}

[1] Anton, Ario., Jatna Supriatna dan Noviar Andayani. Owa Jawa di Taman Nasional Gunung Gede Pangrango. Indonesia: Conservation International (CI) Indonesia, 2011

[2] Ayawaila, Gerzon R. 2017. Dokumenter dari ide sampai produksi. Jakarta: FFTV -IKJ Press.

[3] Nichols, Bill. 2001. Introducing Documentary. USA: Indiana University Press. 